\title{
Down Syndrome Boy Loving History Books
}

\author{
Fengzhi Liu
}

\section{Interview with Mr. Wei Yang's Mother}

Wei Yang, male, born in 1983. Only child. Grade III intellectual disability. Graduated from Miyun School (a special school), Hongkou District, Shanghai. Joined the Sunshine Home in Hongkou District in 2005.

Interviewee: Huiqin Wang (Wei Yang's mother)

Interviewers: Fengzhi Liu, Puyu Zhang

Writer: Fengzhi Liu

Interview dates: October 22 and December 27, 2016

Interview places: Wei Yang's home, the Hongkou District Disabled Persons' Federation

\section{A Lucky Child}

Wei Yang's mother: Before I got married in October 1981, Wei Yang's dad and I were engaged for 5 years. He was born on 13 August 1983 when I was 25 years old (lunar calendar age 27). Before I retired, I worked at the Sixth National Cotton Factory in Shanghai. His dad was an office administrator in a neighborhood factory that processed plastic bags.

Q: When did you find out about the child's condition?

Yang's mother: It was after he was born. But before then in my ninth month of pregnancy, the doctor said the baby might be underweight and asked me if I wanted to come into the hospital for the rest of the pregnancy. So I spent 2 weeks in hospital. Suddenly, one day I couldn't feel the baby moving and told the doctor. He said let's

F. Liu $(\bowtie)$

East China Normal University, 3663 Zhongshan Bei Road, Shanghai 200062, China 
do a blood test. At that time the Maternal and Child Care Service Center wasn't very well equipped, and they didn't have the equipment, so they asked my family to take a blood sample to the First People's Hospital. But on that day, their test machine was out of service, and it had to be delayed to the next day.

When the result came back, they said it wasn't good news, the baby had fetal hypoxemia and I might need an emergency caesarean. All the doctors were off duty, so I had to wait for the next morning. The operation started at 8 a.m. and was finished by 11 a.m. The doctor told me: "Your child might have fetal hypoxemia, but he looks fine." We couldn't tell then, if the child had Down syndrome because he was a pretty baby, small eyes with double-folded eyelids, curly hair and white skin. Even the doctors couldn't tell if anything was wrong. As it turned out, the baby had two problems; one was fetal hypoxemia, another one was that he was very small. He was 2 weeks premature, weighing just a little over three and a half pounds. The doctor said to feed him well and that might bring him back to good health.

When I was discharged, they wouldn't let him leave hospital with me and kept him in an incubator. Once, when the nurse was feeding him, I saw a mark on his head (points to the back of her head with her fingers). It looked like a sore, the doctor dressed it later. After 3 weeks, the sore became infected, and I said to my husband: "It's not doing the child any good at all leaving him here for longer." Then he said to the doctor that we wanted the baby to come back home with us, and he agreed.

I looked at him when he was in my arms and I was very upset, so upset. By now, there was a big hole (makes a shape the size of a badge with her fingers) on the back of his head! His dad is a very caring and careful person and he changed the dressing every day, leaving the wound open to the air when he was home: the weather was hot, and we didn't want the wound to become infected again. After that, it healed in a week.

The doctor told us the child's light body weight was a birth defect, and I would need to care for him all the time. I got some help from his grandparents. When he was 4 months old, and ordinary children would start reacting to the sounds around them, my son didn't. In fact, he couldn't turn around. His granddad said: "Why doesn't he react when I knock a cup or a bowl?"

So I took him back to the hospital and the doctor said he couldn't see anything wrong with him. He said to me: "He isn't active at the moment because he's underweight. Compared to other newborn babies, he's too small." At that time, I thought to myself, if the doctor says he isn't healthy, I'll have another child. It might be hard work, but bringing up a child is always a handful, I can certainly bring up two children at same time! But the doctor said: "I can't tell if your baby has a serious problem, but you shouldn't have a second child." If he is diagnosed with Down syndrome, and I had a certificate of the official diagnosis to prove this, I would have been allowed to have a second child. ${ }^{1}$ But the doctor wasn't able to give me that

\footnotetext{
${ }^{1}$ Having two children was allowed by invoking a special phrase under China's long term 'one-child policy,' which was formally implemented in 1982, and ended in 2015. According to the national family planning policy, civil cadres and workers and other city residents, a couple is only allowed to have one child except when they have one of several 'practical difficulties', for example they will
} 
document at that time. He said: "We'll see the child again when he's a year old and check his condition." So I had to go back home without family planning permission.

He was a lucky child really, on his first birthday, August 13, he suddenly started understanding all kinds of things, just like other children of his age. He'd be sitting in his pram - the old pram was a humble thing in those days - if he needed to pee and of course he couldn't say anything, he'll erm... (She mimes a moving and struggling baby), then I knew he needed to pee. Another thing we noticed was, if we knocked on a bowl, he would start to turn his head around to see where the sound was coming from.

So I went to see the doctor again, and told him about these changes. He said the child should be fine, but his premature birth and light weight was making him develop slower than a normal child. This diagnosis changed my mind and I gave up on the idea of having another child.

He started to talk when he was one and half, almost 2 years old. But he still couldn't tell us if he needed the toilet. Every morning, when I put him on the potty if he needed to poo, he wouldn't stand up. Then I knew what he wanted to do, but he couldn't tell me; he couldn't walk either. But he looked as though he was able to understand something. If I put a horn recording radio $^{2}$ on his desk, he'd tap his hands here and there and move around.

Later, maybe when he was about 2 or 3 years old, his face started to change (the child started showing signs of Down syndrome facial characteristics). One day, I looked at his face, and the distance (shows the distance between the eyes) is getting wider. So, I took him for a blood test at Xinhua Hospital, and the result told us clearly that he had Down syndrome.

Now he was almost 3 years old, and I would be allowed to have a second child. ${ }^{3}$ The doctor said if I got a document from the subdistrict office, I'd be able to have two children.

At that moment I was thinking about this over and over. He's a toddler already, if I had a daughter that would be fine, she'll look after him when he grows up. But if it's another son, what will happen to him? To raise a son, (she refers to the interviewer) you're too young to understand this situation... you're unmarried so you don't know. A son will always be controlled by his wife after he gets married. I thought, this won't work, if he has a young brother, he might not look after him once he gets married.

Also, I was worried that a second child might have the same condition-health and medical conditions were so far behind in those days-nowadays pregnancy tests can tell you everything. This kind of medical technology was unavailable at that time. What would I do if I had another disabled child?

be allowed to have two children if their first child suffers from a physical disability, mental illness, or an intellectual disability.

${ }^{2}$ The 'horn recording radio,' which she's talking about refers to a large portable radio cassette player, a very popular family music player in the 1980 s.

${ }^{3}$ According to the national family planning policy, even if a family meets the conditions for a second child, there has to be a 3- or 4-year gap between children. 
At the same time, I was worried that I wouldn't be able to give much attention to my son if I have a second child; the little one would need to be looked after as well.

Although his grandparents liked him very much, even though his paternal auntie didn't, I don't think they would have loved him so much even if he'd been a healthy, normal baby. We didn't have much money, both my husband and I worked in the neighborhood factory. I worked in that factory for 10 years until they moved out of the neighborhood. When the factory asked if anyone wanted to be reemployed in a textile mill for more money, I took the opportunity.

If we had a second child, then I would have to spend a lot more money on his or her education and university tuition and have nothing left for the disabled child. I was thinking about all of these things, and eventually I made up my mind not to have a second baby, but to bring up the first as best I could. This is why we don't have two children.

Q: Did he live with his grandparents when he was little?

M: We all lived together in the same Tingzijian ${ }^{4}$ but it was divided in two-we were in the front, and his grandparents lived at the back. Wei Yang stayed with them when my husband and I were at work. When my son was older, he liked to lock the door to our space and wouldn't allow his grandparents in. Now both of them have passed away; his grandpa died 18 years ago, his grandma died over 20 years ago.

Q: Did his grandparents keep him company all the time or did they have other things to do?

Yang's mother: They stayed with him all the time. But Grandma wasn't very well, she developed Alzheimer's disease. Grandpa would take her and the child out for breakfast and buy food and vegetables for the evening meal. He would cook lunch and then they would go out again when he played mahjong. Grandpa took Wei Yang with him everywhere he went. They only came home when we returned from work. At that time, his dad was very busy, he was an official in the factory. My factory operated round the clock, three shifts, if I was on the afternoon or night shift, both my husband and I wouldn't be home in the evening, and his grandma would put him tobed.

Q: When he was young, except for his grandparents' company, did he have any professional help in a rehabilitation institution?

Yang's mother: No, he didn't. Once his paternal auntie introduced us to some medicine, I can't remember the name now. She said it would good for his condition, but it didn't work for him. We didn't send him to a rehabilitation institution for treatment because his condition was different, much better than other children who had the same condition. He could walk and talk, he was able to read, we didn't worry so much. While his grandparents looked after him, he wasn't stuck at home all day, which would have been bad for him; they took him out every day.

$\mathrm{Q}$ : Did you try to do anything to develop his intelligence?

\footnotetext{
${ }^{4}$ Tingzijian refers to a north-facing small room, usually a servant's room originally at the corner of the first level of the classic, well-known 19th century multi-floor homes, Shikumen. More information about Shikumen residences can be found at these links: https://www.travelchinaguide.com/ attraction/shanghai/shikumen.htm or https://en.wikipedia.org/wiki/Shikumen.
} 
Yang's mother: I would take him to the park when I was free. I didn't have the time to do any kind of intellectual development with him, because I was working three shifts. His dad was always very busy, too. He left home early but came back very late. My time was taken up with all kinds of housework, shopping, cooking, washing; we didn't have a washing machine or anything like that. When he was older, I didn't even have time to help with his homework. I only realized he could read when I saw him with a newspaper one day.

Q: Did you try to teach him?

Yang's mother: No, we didn't. But when I discovered he liked music I bought him some tapes to play with. When he was a child, I also bought his favorite cartoons like Mr. Black, Little Dragon Mermaid, and Monkey King. ${ }^{5}$ We didn't teach him in a formal way, but took him out often. His dad usually took him out to play; sometimes I'd join them as well. If I worked two morning shifts, two afternoon shifts, or an evening shift schedule, I was able to take him somewhere when I finished.

Q: Did he go to a nursery when he was young?

Yang's mother: He only spent one semester in a nursery, because he was excluded for bad behavior. He was very naughty back then, beating and biting other children (with a resigned smile). He liked to stay away from other children and play with his toys. If other children saw him and tried to grab his toys, then he would fight back.

\section{One of the Best Students in His Special School}

Yang's mother: He was very small when he was born, and he grew into a skinny boy, not as big as he is now. When he was nine and ready to go to school, I was afraid when he arrived to register that they might react to his condition and reject him. So I tried to talk to a teacher in an ordinary primary school and told her: "My son is the right age for school, but he isn't in Shanghai right now, can I bring him to your school next year, when he grows up a little bit more?" But I didn't tell her that he had Down syndrome. She was a very good teacher, and she said: "It's no problem, bring him to us next year, please."

He enrolled at that school the following year, but he couldn't study because he was still too young. His classmates were reading and studying in class and he couldn't understand what to do. One teacher said me: "Your son doesn't really fit in here; he needs a special education school." At that moment, I was... I cried again. I had to think about what to do next, every child needs an education. He had to go to school; he mustn't stay at home.

He could already read very well when he was school age. You might ask, how could he do that? It was because we subscribed to Xinmin Evening News when he was five, and one day I saw him holding the newspaper and he looked like he was

\footnotetext{
${ }^{5}$ All of these three are very popular TV programs from the 1980s. Mr. Black was a famous Chinese cartoon for many generations.
} 
reading. I asked myself, how could he read? His dad said: "I don't know either. He just picked up the newspaper and looked like he was reading."

His grandparents looked after him until he was ready to go to school. His grandpa liked to play mahjong and my son would always sit next to him and play with his own game. He has a very good memory, he learned to recognize and remember the words on mahjong tiles after he heard people call them out such as: "East wind, whiteboard."

At first, I couldn't work out how he could read, but after I gave it some thought, I realized that he had memorized all 144 mahjong pieces! There are characters and numbers, like "fortune" and others, and this ability of his made me determined that he should get a proper education; he has to be independent one day.

After I was let down by the ordinary school, I took my son to the Hongkou District Welfare House. The teacher asked him a lot of questions like "Where do you live? What's your mom's name? What's your dad's name?" My son answered all of them. When he was younger, about six, more or less, he could talk to the doctor about his pain or symptoms without my help. After the interview, the teacher said: "You shouldn't leave the child with us, we won't be able to teach him very much. We're just a kind of children's nursery. You should take him to a special school." I didn't even know there was one! Then I found out that there was one on the Tianbao Road. The teachers enrolled him when they saw his condition.

Q: How long was he at the ordinary school?

Yang's mother: Probably about 2 months, but he couldn't stay there any longer. His face revealed everything, even though some children who were less intelligent than my son could stay on.

Q: You mean he had to leave because he had Down syndrome?

Yang's mother: One thing was his condition, another was he couldn't keep up with the other students.

Q: Is there a big difference between the two kinds of schools?

Yang's mother: The teaching materials are similar; the ordinary school has its own standard textbooks, but the pace of learning at that school was difficult for him. The difference is that the special school, the Miyun Road School, has a much lower standard of learning, because those children with special needs have a slower learning ability. For example, my son is in his $30 \mathrm{~s}$, but his intelligence is only equal to that of a young teenager. When he started school at 10 , his brain was only developed to a level equivalent to that of a 5 or 6 year old. ${ }^{6}$ That's why he couldn't keep up in an ordinary school. The first year's teaching schedule and material at the special school is the same as the final year in a nursery. They only start to study at the level of an ordinary first grade when they have reached the second grade in the special school. There's quite a difference between the two kinds of schools.

Q: So the gap is 1 or 2 years?

Yang's mother: Probably more than that, say 3 years. After he transferred to the new school, I stopped worrying about him. The teachers liked him because he was

\footnotetext{
${ }^{6}$ Down syndrome patients usually have intellectual difficulties that gradually increase with age; their IQ is usually between 30 and 55 .
} 
very well behaved in class, never screaming or running around like some of the other children, and he always listened to them.

At the same time, he was a good student; there were over ten in the class, divided into three groups: good, average, and poor. He was in one of the top groups. He always handed in his homework on time and finished it on his own. I didn't interfere with his study very much at all, because I thought being literate would be enough for him; anyway this school wasn't an ordinary school. Usually he finished his homework after he came back from school and then I'd take a look; the answers were always right. This really gave me peace of mind.

He liked to play mahjong with his grandma after he finished homework. He's liked mahjong since he was very young, and always bothered us for a set. But I didn't play with him.

When I went to parent's meetings, the teachers never discussed his homework, never said anything about it. But sometimes I was called to the school because he'd been misbehaving, fighting for example, but study was never an issue. As for his popularity, I never worked out a reason.

Q: Fighting with somebody? Was he a naughty boy?

Yang's mother: He can be very naughty; I had to pay compensation to some students several times. And I was a regular visitor to the teacher and the headmaster's office. His teachers usually called me directly if he'd bitten or beaten someone. The teachers still liked him a lot though, maybe because he was such a good boy, with good manners. At the present place, the district DPF center, all the teachers like him.

Q: What did they learn in the special school?

Yang's mother: Basic subjects, like music, math, PE, drawing, singing, and other things, at a very simple level. They didn't have a politics class because that would be beyond them.

Q: Which subject was his favorite?

Yang's mother: It seemed he was good at math, Chinese, and singing, but not so good at drawing and PE. His math and Chinese test scores were usually over $90 \%$.

Q: Do you remember anything during his schooling which impressed you?

Yang's mother: Not really, but he seemed good at studying. The teachers always gave him good marks for his homework, he rarely asked me questions. Sometimes, if I saw a wrong answer, I would ask why he made that mistake and explained the question to him again.

Q: Did you reward him for good marks?

Yang's mother: Yes, of course. We would go out together or I'd buy him something delicious, although back then there weren't as many tasty snacks as today. About 2 years before he graduated, he asked me for a mobile phone, but back then very few children had one. Even me. But his dad had one and he passed this old phone to my son after he bought a new one. He used this old mobile phone, and remembered the numbers of all his family and relatives. The mobile phone made things easier sometimes, too, he could call us if he was going to be late. Like the time he called me when he got off the bus at the wrong stop and explained where he was over the phone. I told him what to do and he came back by taxi safely. It was a relief that he had a mobile phone, I have to say. Anyway, after school, he didn't like to hang out 
with the other children, but came back home straight away, finished his homework and played later.

Q: Did he join in any activities when he was at school?

Yang's mother: The school organized all kinds of activities, visiting different places quite often; he was always joined in these events.

Q: Did they have some performances?

Yang's mother: I don't remember if they did, but they went to shows outside school sometimes. These children didn't draw so much public attention in those days, it's very different today. Now his school has a lot of student activities and performances. They never had such opportunities before, things have changed. Especially since Shanghai hosted the Special Olympic Games in 2007. It seems they are able to do better things and society pays more attention to them. It's very different from before.

Q: Did he play with his friends when he was younger?

Yang's mother: No, he didn't play with other children at all. Because he hardly went out, although he would never agree or argue when I told him to go out and play. He just stayed at the side and did his own thing.

He was a naughty boy when he was little. He's an introverted child, doesn't like his stuff to be touched or touch other people's stuff. If somebody grabbed his toy, he would fight for it and wouldn't let it go easily. Once, when he was little, he wounded another boy's hand when the boy took his toy. He was never interested in other children's toys either. His young cousin, his paternal auntie's son, would often leave his toys in the yard. If my son saw them, he would take them back to his cousin's place, and never kept any of them.

Q: Did he get on well with classmates at school?

Yang's mother: I'm not sure about his social relationships at school, but I understand that he's quite introverted there, too. He had good relationships with his teachers, and he would rather play with adults. If he saw an old man telling a story about an emperor in the street, he would get involved straight way. He didn't play with other children.

It's quite strange, he isn't an active person, doesn't like active games either, never liked football. He prefers quieter games like bowling, dancing, playing a drum, rather than jumping around like other children.

Q: Did he have a close classmate?

Yang's mother: He didn't like to play with other children, but he told me he got along quite well with the class monitor, a girl. But I don't know her name.

Q: Did he stay in the same class until he graduated?

Yang's mother: He changed places a couple of times. In the beginning, he enrolled at the Special School of Tianbao Road; 2 years later, he transferred to the school at Miyun Roadand joined a bigger class with his teachers and classmates.

Q: Did his teachers encourage him to play with his classmates?

Yang's mother: I don't know. Because he's one of the good students, studying hard, taking homework seriously, the teachers didn't try to influence his social behavior. They knew he liked to play alone, and wasn't interested in playing with the other children. 


\section{Learning to Be an Independent Person as a Child}

Yang's mother: When he was a child, around five, I started teaching him to go shopping alone at the local store. Sometimes, he'd come back and ask me for candies when he saw the other children were eating them. I'd say: It's rude to stare at other children when they're eating, they might get annoyed. Let me know if you want to have some snacks, and I'll buy them for you. He never forgot that lesson. In a situation like this, I just tell him: "It's all right, you can buy them yourself." The store was just on the corner; it was very convenient for him go there for some snacks.

One time, I ran out of change and wasn't sure of the price of the thing he wanted, so I gave him a big note. When he walked away from the counter without change, the shop assistant stopped him: "Oops, little one, why did you forget your change? Are you a fool?" He was so annoyed and screamed to me when he got home: "Mom, they said I'm a fool!" And he insisted that I go back there with him to confront the seller. I couldn't work out why the assistant would insult a young customer like him, so we went back to the shop together. I found out what had happened and explained that the assistant had said that only because you forgot your change after you had paid.

Another time, when he was little, preschool age, he went to the barber shop alone to have his head shaved because he was losing his hair. But he came back home with a shaved head and eyebrows! I asked him where did your eyebrows go! He was very angry and ran back to the barber and shouted at him: "Why did you shave my eyebrows off, you have to give them back!" After that, he never let the guy touch his hair again. He loses his temper with some tiny things very easily, and won't let them go for a long time, "If you insult me, I'll turn my back on you," that's the way he's been since he was a child.

Q: When did he start being independent, like washing his face, or cleaning his teeth?

Yang's mother: When he was very young, he could wash his face and he could dress himself when he was very little: he's a tidy person. He started school quite late, at 10, but began washing himself around 8 years old. He'd shower every day, his dad would take him to the bathhouse every day because we didn't have a bath at home. When we got a bath installed at home some years later, he couldn't control the shower, but liked to wash himself after we ran the water for him. He's a tidy person, I remember one time he had loose bowels at school and ruined his pants; he ran all the way back home to take a shower. Fortunately, his paternal auntie was at home and ran a bath for him. I was surprised to find his dirty clothes on the floor when I came back at lunchtime; then his auntie told me what had happened: "Your son came back for a shower and now he's gone back to school."

Q: Did he ever cry when you left him at primary school?

Yang's mother: No, he was never a crybaby. He's grown into a strong boy, maybe because he went out quite a lot; to his grandparents for breakfast, or food shopping, or to grandpa's afternoon mahjong game every day. He didn't even cry when he was 
a baby. He always had a very good appetite, I even had to make an extra hole on the nipple of his feeding bottle (she bursts out laughing).

When he went to school at Tianbao Road at first, we had to take him there, but soon he could walk to school alone. He could read and remember the names of the roads. Several years later, when he was in the fourth or fifth year, well, actually it was his third year, the school moved and merged with another. The new place was far, far away, a bus journey; the first couple of times, we went to school together and I kept explaining where the bus stops were at both ends, where to change, how many stops the journey would take, where the breakfast shops were.

You see, he used to have breakfast out with his grandparents, this morning he's at home only because of the rain. Even when he goes to the Sunshine Home these days, he still does this, buys his own breakfast every day.

On the third day at the new school, I told him to take the bus journey on his own, but I followed behind him. If he got on the bus through the front door, I would go in the middle door and hide from him, then I'd get off at the same stop. I could see that he was pretty good at taking the bus and stopped worrying. But I still followed him one more time before he really travelled alone. After graduating from school, he only asked for our help to pick him up if he went somewhere new for a performance. Usually he was independent.

Q: He is a pretty able child; do you think you're too strict with him?

Yang's mother: No, I'm not a strict mother; I just have some rules that I have to explain from time to time. For example, it's not very nice if you stare at people while they're eating, better to buy your own snacks. I don't have too many rules because he doesn't like going out very much. I just let him do things his own way. I show a lot of leniency, and I'm happy with his behavior and proud of his achievements.

He used to let me wake him up every morning, but wouldn't trust his dad in the same way. If I wasn't home this morning, he'd be nervous about being late. Usually, he heads off to the Sunshine Home at 8 a.m. I wake him before that, and then he washes and gets dressed, he leaves and has breakfast at the store on his way to the home.

Another thing is, because of his diabetes, he needs monthly blood tests; he goes on his own for these as well. The day he goes to hospital, his schedule changes; he gets up, dressed, walks to the hospital, does the test, and has breakfast afterwards- then he goes to the Sunshine Home from there.

He also goes to hospital for a saline drip without my company if he's ill. He can travel to the city alone, take the bus to his maternal grandma's place, or his maternal big auntie's home at Dinghai Bridge Road.

These days, after his weekend training at the district DPF center, it doesn't matter how cold the weather is, he always likes to have a shower. After he changes into clean clothes, he likes surfing online, but he doesn't play online games much, he prefers mahjong, poker, or Fight the Landlords. ${ }^{7}$ Most of the time, he watches programs about history, particularly stories about the emperors. The rest of us only get a chance to

\footnotetext{
${ }^{7} \mathrm{~A}$ popular poker game in China, played by three people with one or two sets of cards.
} 
use the computer after he goes to the Sunshine Home, but we have to give it back to him when he comes home.

\section{Mixed Feelings About the Sunshine Home}

Yang's mother: He studied quite well; I never needed to worry about him. My worries started when he graduated in 2005. At that time, I was working in the cotton factory. I had to think about what he'd be able to do if I couldn't let him stay at home on his own. When he was at school, he would go out regularly and it was good for his social skills. I didn't know what would happen to him if I kept him at home all the time, it was a huge worry.

Later, I learned about two things that he could do; one was a baking course, the other was that a Sunshine Home had opened in the community. A couple officials from the subdistrict office visited us, asked about him, his condition, experience, and other details. Compared to other students at the home, my son is in a better condition than many of the others who had never been to school. They told me about the Sunshine Home that had just opened, it was in our community, very close, just one bus stop away. After thinking about it, I decided to send him there.

The reason we didn't choose the baking course instead of the Sunshine Home was the distance; the latter was very close, easy and safe for him to walk there. But the Sunshine Home was a new thing, I knew nothing about it, I thought we'd just give it a try. I felt confident because he could find his way there and back; also, finally he had somewhere to go. I was relieved because now he had some independence.

Q: Have you ever thought about sending him to a junior vocational and technical school, to learn some job skills?

Yang's mother: There wasn't such a place when my son graduated. That wasn't available until the second year after he'd left school.

Q: And now, does he always go to the home?

Yang's mother: From Monday to Friday, he's always there.

Q: So, he goes to there every day. What does he usually do there?

Yang's mother: Yes, he goes to the Sunshine Home every working day. There isn't very much going on, they don't teach them a lot. They'd do a special class when you visit, but normally they don't have educational classes. Every morning, they do some physical exercise to start, then back to their seats and sit there.

My son doesn't like one of the teachers. These children are bright, they're smarter than you think, but this teacher always orders them to do this or that, her style annoyed him. So, he never engages with her teaching, just writes in his reading diary, the story he read the night before, or does some origami, making a wastepaper basket for the lunch time rubbish. It's why he asks me to buy paper sometimes.

Q: Don't they have classes? I saw them learning adding up with an abacus last time.

Yang's mother: Yes, they have an Abacus class; he didn't like it at the beginning. The teacher told him it won't work like that, and reported him to me as well. So I 
told him, if you study there, I don't care about your results, but you have to engage with the class. Then he started to pay more attention.

Q: Did he start to learn how to use the abacus when he joined the home?

Yang's mother: No, the class started last year. It's probably a special class created by the district DPF office, because all the Sunshine Homes in the area are running the same curriculum.

Q: Do they learn anything else?

Yang's mother: They had drawing classes, that was a very nice teacher who taught drawing and singing, but he left and nobody replaced him.

Sometimes my son plays mahjong during their free time, he likes the game; he likes to invite the other children to play, otherwise, he'd watch TV.

Q: When he first went to the Sunshine Home, was the overall environment the same as it is right now?

Yang's mother: There were more severely disabled students than today; quite a lot had been kept at home and they hadn't been schooled before. When they first came to the Sunshine Home, the teachers did some simple stuff for them, but my son didn't like these courses, because he'd already learned such basic things at school.

Q: What do you mean by "simple"?

Yang's mother: It was about their life skills. For example, how to put on your shoes, how to get dressed. Some children couldn't do these very simple things, they couldn't even feed themselves, and they were spoon fed by their parents at home; but now, all of them are doing much better. My son was very independent, very good, those courses weren't suitable for him. Another example is how they got home; my son walked to school on his own all the time, but some children were totally dependent on their parents: these children had never been school. Their parents cared about neighborhood gossip too much; they didn't dare take their children out, just kept them at home.

Q: Do you think there is anything the Sunshine Homes need to improve?

Yang's mother: I think this Sunshine Home is poor. I heard that some homes do more things, like dancing or something else. So there are a lot of things they need to change and improve, better quality teachers, for example. Some teachers aren't very well trained; they don't have any new things to teach. There's a teacher who is over 70; a two-generation gap with the children. She is always talking about her own experiences, what she did when she worked at a subdistrict office. How can these children understand her old stories? They've never heard of such things before.

Like my son, he is a big fan of history; he read a whole set of books about the 12 emperors of the Qing Dynasty. He's working on modern Chinese leaders' stories now, Zedong Mao and Xiaoping Deng's generation. He's reading a book on Zedong Mao this moment; he knows Chairman Mao's birthday is on the 26th. These days, not many young people like history like my son does, reading books, asking questions, discussing it with his dad. There is no way he could understand the teacher's personal stories from the 1970s. Students don't like it.

Some other homes are already doing the Ninth Edition of the People's Radio Calisthenics, but here they still practice the old version. The teachers are not bothered about guiding them, they just let students do the exercise in their own way, and they 
don't care. The students just sit there and watch TV programs afterwards, then they have lunch and sleep at their desks until 2 p.m. Then, it's clearing up time before they go home; some children sweep the floor while others mop it.

Q: So you mean the home needs some new blood?

Y's mother: Today, children are very different from in the old days, much smarter. They are different from the ones who first went to the home; it's why this place needs new teachers with new ideas and knowledge. But here they do bring in more new people, but they should also have some new ideas.

Why does our district DPF drum team have so many children? Because there's always something new going on. Teacher Zhou is good at choreography, teaching different dances from time to time, all the children love it.

But at this home, they have lost some children already because the teachers repeat the same things all the time. At least my son plays mahjong; some children do nothing, they just sit there, waiting for lunch time, waiting to go home. Some parents tell their children: "Just go there anyway, let us have a break at home, at least the home feeds you." For some children, it's the only reason they still go.

I don't have any other choice, even though I know he doesn't like to be there. The home does a roll call every day; low attendance makes you look bad, it tells people the teachers aren't good enough. Here there should be more than 30 children, but usually only 20 come. I don't have a choice, so I have to say to Wei Yang: "You'd better go, you have to go."

Q: Did he participate in any activities?

Yang's mother: Yes, he did. For example, he joined the drum team of the DPF office in Hongkou District, with a dozen classmates. Years ago, they had a choir and went to Heping Park for shows. The teacher in charge of the choir was a very good teacher, he chose Wei Yang as the conductor. But these activities were only kept up over the first several years. They didn't do these things for very long.

Q: I've seen your son's photos on the home's wall, one I think of him with a visiting leader?

Yang's mother: That's a long time ago. He's always had a bit of luck... hard to tell why exactly. People always like him wherever he goes; leaders like to take their photo with him, too. There's also a photo of him at his birthday party at the home. That day he told me he wanted to have his birthday at the home, so I bought him a birthday cake and some drinks to share with his classmates.

\section{He Grew Up with the Special Olympic Games}

Yang's mother: I'm a working mom; I didn't know anything about the district drum team before he joined the Sunshine Home. How can I say this... You should know, a family with an intellectually disabled child... We feel that outsiders look down on us, on the child. It's heartbreaking when he's despised by his own cousins, the children of his paternal uncle and auntie. 
One day, he told me, a classmate's mom had asked him if he wanted to join the drum team; she was the vice chairman of Zhiqinhui, ${ }^{8}$ an organization for people and families like us. I asked him: "Do you want to play the side drum?" He said yes, so he joined. As parents of an intellectually disabled child, we are a bit... a bit inferior when we meet other people. I stay in our own world; I don't know very much about the outside world. But that time, I thought about it again and again, and I decided to let him have a go.

This drum team has a long history. In the beginning, the founder, an elderly man who worked at the district DPF office, tried to set up a band. There are lots of intellectually disabled children in the association, some are mentally challenged, some are normal but their brain has been damaged by disease, but my son is a Down syndrome child. The vice chairman said tome: "Please let the founder have a look your son." The guy liked him straightaway and said: "Wow, I didn't know there was a child like him in your area, of course, we want him!" He wants Down syndrome children, the more, the better; but he can't use severely disabled children. Finally, my son joined his team.

Playing the side drum has a formula, it's a kind of mathematical formula, he practiced the rhythm and hand movements at home, it was quite hard. He also went to Heping Park to practice every Saturday. One Saturday, I met two teachers there, one was the vice chairman, they said: "Wow, you're Wei Yang's mom, he looks like a smart boy!" I was so happy when I heard this (see Fig. 1).

Later, I joined the class with him, I learned how to play first, and then taught him at home to help him learn more quickly. After some time, he seemed to get the hang of it.

One day, he was called in by the district DPF office, so all three of us went there together. The place is on the Guangzhong Branch Road. Then we found out that he was invited to join two classes: English and dance. He couldn't speak English at the time, but there was a dance class after the English class and he enjoyed this and became a good dancer. Once his dad and I went there and watched their dance, his beautiful performance touched our hearts.

Since then, he trained every Saturday and Sunday. I joined them to learn and volunteer when I was free. He's been with the team for around 5 years now, the teachers spend so much love and attention on all of them.

At an election of the district Association of Persons with Intellectual Disability and their Relatives board, a worker in the district DPF office asked me if I'd like to stand for the vice chairman's seat. The incumbent vice chairman, a physically disabled dad who had an intellectually disabled child, had to leave because of old age.

At the time, I'd been laid off from the old place. My new job was as a community worker for the subdistrict office, coping with public security and hygiene issues and I had more free time than before. So I took this volunteer job in the end.

\footnotetext{
${ }^{8}$ Here, Zhiqinhui refers to the district branch of the China Association of Persons with Intellectual Disability and their Relatives.
} 


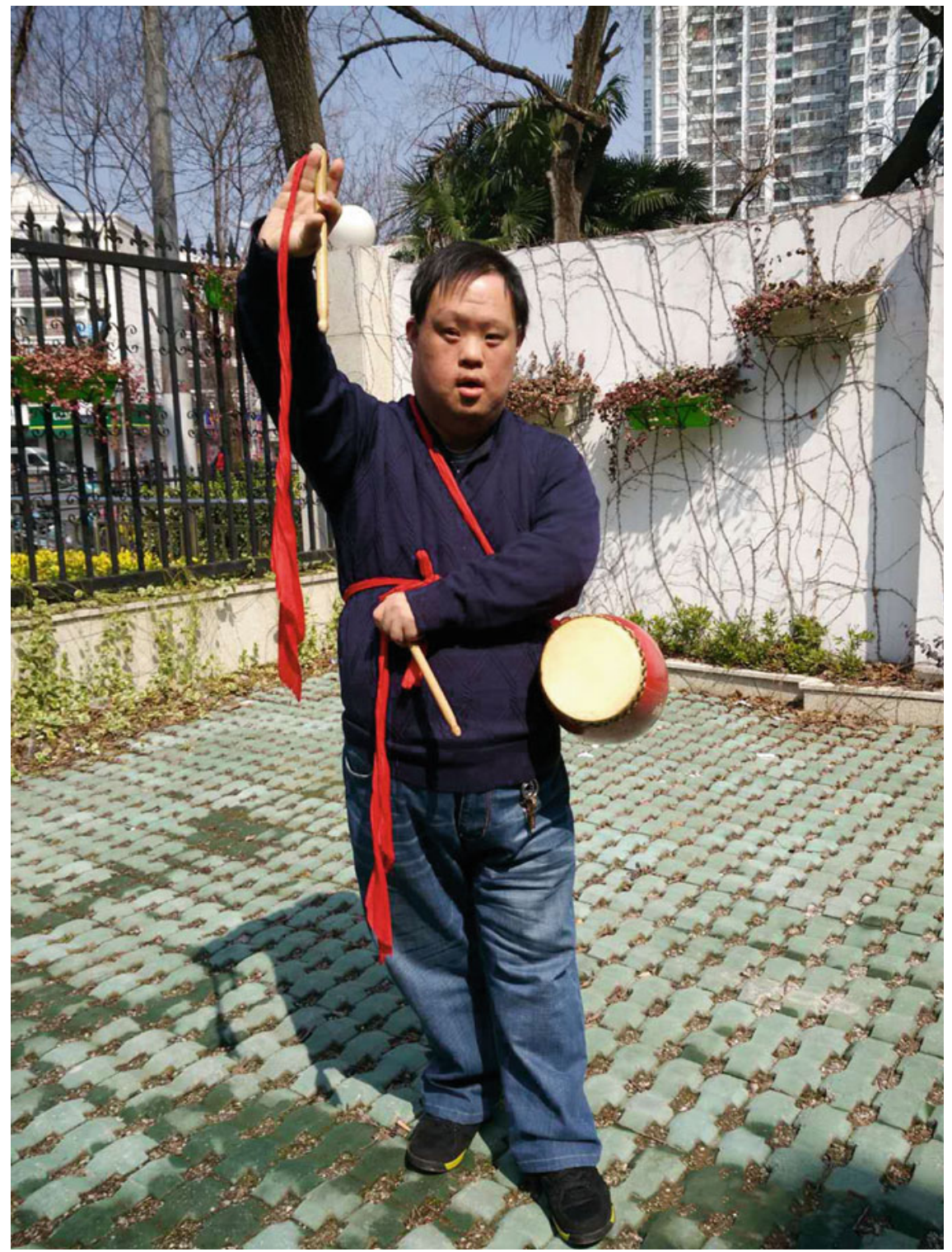

Fig. 1 Mr. Wei Yang practicing side drum

The drum band trained up to three times a week; Tuesday afternoons and Saturday and Sunday mornings. The new day job gave me more time on Tuesdays, so I started going to their afternoon classes, and I got on well with the teachers. It was always a happy time being with them, we had that one thing in common, a special child at home. We had so much to share, children, family, and we could speak our minds to 
each other. The kind of things I couldn't talk to my colleagues about, joining in the workplace chatter, especially when they talked about their college children, there's nothing I could say.

Those years were the worst part of my life, imagine, even his own paternal uncle and aunt called him an "idiot," it hurt so much. The pressure made me lose my temper all the time, because I was so hurt; but his dad was a really good-tempered man. So, the teachers invited me: "Why don't you join us as a volunteer?" They had a team of around nine people at that time and I got on well with all of them. So I became one of them, a volunteer, also a district DPF teacher.

Special Olympics came to Shanghai after my son had been at the home for a while; this was the 2007 Special Olympics, Shanghai Special Olympics. ${ }^{9}$ It was his first bocce competition ever. On October 1, well, it was the second actually; I had to visit my mom who lived in the Pudong New District, while my son went to the event alone with a disabled assistant from the subdistrict office.

That morning, he told me: "Mom, I'll bring you back a gold medal." I replied: "Well, I'm just so pleased you can go in for this competition, the Olympic Games, a national ${ }^{10}$ game, I'm so glad you can be part of it." I thought I'd be completely thrilled if he won a silver medal, so I told him: "Just concentrate on the game, try your best, and meet me later at Grandma's place." Around noon, he phoned. "How's the competition going," I asked him. He said: "Mom, I won a silver medal." Wow, I was so delighted and crying at the same time, I just cried at my mom's place.

All I could think was, my son entered Special Olympics and won a silver medal; most normal people couldn't compete at this level, right? So I really cried. When he came home that evening, he really was proud of himself, so were his dad and me, too. His paternal aunt smiled but you could tell there was a very different feeling. They just looked down on him, but their attitude did change a little bit after his win.

My big sister was very pleased for him too. She told me: "It's been such a hard job for you to raise this child and now look what he's achieved." At that moment, I couldn't explain my feelings in words, I had a sleepless night, I was awake the whole night.

From then, the Special Olympic Games became a turning point for him. He changed gradually after that; he became a quicker learner. At the DPF center, Teacher Zhou and eight other teachers who cared for him, had been concerned about his studies; from then on, they gave him all kinds of opportunities. And the founder of the drum team let my son join in performances whenever there was a chance. All of those opportunities came from the teachers. Since then, he's grown up bit by bit, going to competitions and games, one after another, winning more and more medals. Once he had a chance go to a competition in Beijing.

He's getting better and better all the time, even though he's a little bit out of line right now. He learned better and faster when he was younger. He was in a

\footnotetext{
${ }^{9} 2-11$, October 2007, Shanghai hosted the 12th Special Olympics World Summer Games, usually known as the Shanghai Special Olympics.

${ }^{10}$ The Game is a global sports festival.
} 
competition $^{11}$ at the Songjiang District yesterday. It was a unified run, ${ }^{12}$ where 12 people have their legs tied and run together. There was heavy rain that day-we were soaking wet. I'd just washed our clothes that morning-but our team had to go. There were a lot of foreign athletes at the competition, everybody had to be there on time, we couldn't let other players down.

Here's some pictures of him at Special Olympics (shows pictures of Wei Yang in competition, and some of his medals), and quite a few gold and silver medals, and certificates of merit. This picture is when he went to The Global Happy Family ${ }^{13}$ event. This one is when he played with the drum team at Heping Park, a performance from our community. And, this is one of him at the Sixth National Special Olympics. ${ }^{14} \mathrm{He}$ has another nice picture (goes through pictures)... I can't find it-he's biting a silver medal—quite nice. But I couldn't find it yesterday (she has a regretful expression on her face), I'll show you when I find it.

Q: He is great!

Yang's mother: Isn't he great (she looks very happy)?

You can tell things are much better these days; there are quite a lot people who care about our son. But years ago, we were... it's hard to describe our situation (sadness appears on her face).

Q: What did you mean earlier when you said he's now "a little bit out of line"? Do you mean he is different from before?

Yang's mother: Since he started playing in the drum team, he's become smarter, but he gets clumsy when he is fat. He was very good 2 years ago, but now, he's getting weaker gradually. At this age, around their thirties to forties, Down syndrome children begin to go backwards. From this point, their condition doesn't improve but starts to decline. These children don't have a long life; their organs are as weak as 70-year-olds at his age. It's why they go downhill from here. My son is different from 2 years ago, he can be awkward and learns slower than before, he can't learn as fast as before any more. This year (she's sobbing)... he's going downhill (she cries).

Q: When was his fastest period of development do you think?

Yang's mother: When he joined the drum team, in 2006, he was improving so well until last year. This year, I realized he has started to age. There are several children with the same condition as him at the home, they are all getting weaker as well.

Q: Are you worrying about his condition?

\footnotetext{
${ }^{11}$ Here, the interviewee talks about 'the Special Olympics Sunshine Unified Run' on 22 October 2016, hosted by the Shanghai Special-Care Foundation and other NGO groups and a commercial company. More than 40 Chinese and foreign teams attended the event. Wei Yang was one of the athletes of the Shanghai team.

${ }^{12}$ Unified Run is a popular game of mixed teams of disabled and non-disabled people. As an extended event of Special Olympics, it encourages two groups of people to cooperate together and understand each other.

${ }^{13}$ The Global Happy Family is a competition run by a famous show, Happy Chinese from CCTV, China Central Television.

${ }^{14}$ The 6th National Special Olympics also known as the 9th National Disabled Games, took place on 12-20 September 2015, in Chengdu, Sichuan Province.
} 
Yang's mother: Of course, but there's nothing I can do, even though I understand his situation. All of the teachers and volunteers think the same: while they are here with us, we should make them as happy as possible, try our best to provide whatever they like (she's crying, and the interviewer hands her some tissues).

Q: How did you find out about the competitions and games that he entered?

Yang's mother: From the district DPF office. When we get the details of a competition from the office, the teaching team will choose some suitable children. My son is usually on the list because he's a popular guy.

The teachers make a huge effort; they are very patient with the children, because the children can only remember things after they have been taught several times; they forget faster than they remember.

Q: Did he join in other sports as well as bocce at Special Olympics?

Yang's mother: He took part in several other games, dance, side drum, waist drum.

We're still going to the district DPF center to practice regularly, every Saturday and Sunday; the weekend practice opens to the public if you want to watch. He also did the dragon and lion dance several years ago, but they don't do this activity anymore. Here's a picture of the show-he is playing the dragon ball. Bingbing Li has donated 50,000 yuan for this event.

Q: Dragon ball is a difficult role!

Yang's mother: You're right; people were surprised at how good he was. This is a picture of him playing the side drum (points to a picture). Our teacher and volunteer team train them every weekend. He's a good conductor as well; he conducts the choir if we have a performance. For one performance, his teacher asked me to find a choirmaster's suit for him, so I dressed him up in his grandpa's shirt.

This is Teacher Zhou that I talked about (points to a woman in the picture). Her child has multiple disabilities, he is disabled physically and intellectually. But she brought him up to become a college student and now he's graduated. She's a very good teacher, really, she teaches them to sing and dance, choreographs the team, too. Here's the founder of the drum team (finds another picture), his family name is $\mathrm{Ni}$, so everybody calls him Uncle Ni. This one, the event didn't finish until 10 p.m. that night, it was called "Shanghai Top Ten," but I can't remember the meaning of the ten. This one (moves to another picture) is the "Shanghai Disabled Performance for the 90th Anniversary of the Communist Party."

Q: Do you think he has changed a lot since he joined Special Olympics?

Yang's mother: It's been a very big change. Before, he liked to focus on his own things rather than play with other children; he kept away from them. But he liked watching adults play mahjong a lot. After Special Olympics, he started interacting with his classmates, playing mahjong or chatting, and he became part of the group.

His social ability has improved a lot since he joined the drum team. We always let them do group exercises together, dancing, or doing physical exercise. This helped him get closer to the other children; some of their parents were also teachers and volunteers of the band.

We are all on good terms; we usually hang out with our children together, have a meal or go for a trip. So these children get a chance to play with each other. He's quite close to several children in the drum team but he doesn't get on that well with the 
children at the home. Those Sunshine Home students have a more severe condition than my son; they find it hard to interact.

Q: Did it affect your husband and you when he entered Special Olympics? For example, like your feelings or lifestyle?

Yang's mother: Yes, it's affected our family a lot; we are happier and feel better. I used to lose my temper quite easily, but we're delighted now he's grown up, it's very satisfying. We are a more harmonious family.

Q: What is your husband's opinion about your son's involvement in Special Olympics?

Yang's mother: He's very supportive. He was always supportive when our son entered a competition or performance. He's very pleased about the child's achievements as well. In the past, children like him were kept at home by their families and they knew nothing of the outside world. But now...

Yesterday morning we left home at six in the morning for an activity. His dad drove us to the district DPF office on his electric scooter, and then cooked dinner when we came back home at six in the evening.

On the weekends, my son and I have to leave before 8 a.m. and get back in the late afternoon. Sometimes I have to go to the office to prepare for meetings for almost the whole day before the next day's activities; my husband is always fine with this. He says to me: "Please do whatever you need to do."

I used to get angry at home quite often when I was in a bad mood, but now I've changed too, and that makes him happier as well.

He kept working after he retired at 50. But when I retired and tried to find another job, my husband stopped me and told me to look after the child and leave the family finances to him. Now he's stopped working, he does most of the housework, cleaning, cooking, and shopping. I only need to do the washing. As you can see, he even bought me some snacks today. He said he'd be happy if I looked after the child well.

Q: What role do you think a father needs to play in a child's development?

Yang's mother: I have to say, he was a good father when the child was little. He's very fond of children. He took Wei Yang to his factory's social events, like playing mahjong or other games when he was little, sometimes Wei Yang even played charades with other people. Back then, my colleagues liked my son very much, too. My husband would never leave the child at home alone, but took him to his business meetings and dinners with other salesman. He encouraged the child to study hard before exams, used to tell him to work harder all the time. He never complained when I bought things for our son. Neither of us have new phones, both of them are the child's old ones.

He is always patient when the child asks questions, they can talk about everything to each other. Our son likes talking about football with his dad, especially during the World Cup season. But Wei Yang doesn't like to chat with me because I can be quick tempered or because women are always too busy with the housework, we don't have much free time.

Q: I was told by one parent that your son is a real star at the district DPF centerwhat's special about him? 
Yang's mother(smiles): It's all down to his teachers, they are very good teachers. Before the performances, they would teach them one to one, correcting their movements all the time, full of patience. All his development is down to the teacher's excellent hard work.

Q: Last time when I visited them at the district DPF center, I saw they were baking. Do outside volunteers come along to do this kind of activity very often?

Yang's mother: They do a baking class every 2 weeks, probably, they cook different things every time, cookies or cakes, they always do something different.

\section{Enjoying Music and Reading}

Q: Did he show a liking for anything in particular before school age?

Yang's mother: He liked music. I got a big radio cassette player, a double-horn, ${ }^{15}$ when I got married; he really liked to play with it. I usually left it with him when I was working. He would sit down and play with it the whole morning.

Q: Does he like anything in particular or all kinds of music?

Yang's mother: Now he's older he has his own favorite stars; I guess one is Jay Chou, ${ }^{16}$ another is the singer of Red Dust Rolling, ${ }^{17}$ and several other musicians. Before school, he liked Chinese martial arts TV; he played along, copying their actions on his bed when he watched things like the Little Dragon Mermaid and the Monkey King.

Q: What did he like after he started school?

Yang's mother: He liked... I'm not quite sure what, but he likes literature, and writing, he writes at home all the time.

His paternal uncle and his family live with us, and when my son was young, his uncle would sometimes fight with my husband about some family business. My son wrote all of these things down, about when his uncle fought with his dad, how his aunt, his uncle's wife, insulted his mom, he recorded everything. Even though he didn't argue with them, he just wrote everything down.

He still writes now, at the home. His teachers say the same thing: your son is writing all the time when he's here. Why does he do this? He likes reading before bedtime every night, he always reads before he goes to sleep. And then he writes in his reading dairy the next day at the home. Anyway, he writes about things he reads in his books. He likes reading and writing very much, it's a habit with him. He doesn't read everything, only books about the emperors, they are the only books we have. For example, this kind of book (takes out a book about Emperor Tongzhi) a set

\footnotetext{
15 'Double-horn' is the local name for a ghetto blaster, a large portable cassette recorder with two speakers, one of the most popular wedding gifts in the 1980s.

${ }^{16}$ Jay Chou is a popular pop singer from Taiwan, well known around Chinese speaking areas.

${ }^{17}$ There have been several singers who sang this famous song since the 1990s, Da-Yu Lo and Sarah Chen, two very famous Taiwan stars from those days were singers. But another Taiwan singer Sally Yeh, who was also very popular around the 1990s has a similar song. It's not clear which singer or song she is talking about.
} 
of 12 books about 12 emperors. He asked Teacher Zhou to buy the missing volumes in this set for his collection, one by one. He kept telling her which book was missing. Now he has all 12, the whole set. He can talk about those stories after reading. This emperor, emperor Tongzhi, he can tell you about the time of his accession, how long he reined over the country, who his successor was, and so on.

Q: Does he take the book to the home or just write from memory?

Yang's mother: No, he doesn't. He has a very good memory; he can remember stories he read the previous evening.

$\mathrm{Q}:$ He has a good memory, then?

Yang's mother: A good memory is one of his virtues. When Doctor Yang met him when he was a teenager, he said: "You'd better give him cosmetic surgery when he grows up. Because he's smart but his face lets him down. Surgery would make him look smarter." He never forgot these words. Once he was told the same thing by a teacher who works at the district DPF office. My son said to him: "We don't have the money; the doctor told me I'd look different after facial surgery. But we don't have this kind of money; otherwise, I would have had the surgery already!"

\section{It Can Be a Lot of Fun Being with Other Parents}

Q: Are you working as an associate with the other parents?

Yang's mother: The association is for intellectually disabled people and their families, in our subdistrict, I'm the Chairman.

Q: All of them are parents or families of disabled children, aren't they?

Yang's mother: Yes, it's a social organization; there are five non-government organizations under the district DPF office, associations of intellectually disabled people, those with a physical disability, deaf-mutes, mental problems, and blind.

$\mathrm{Q}$ : What's your main duty in the association?

Yang's mother: We're under the management of the district DPF office; they assign tasks to us when the district government produces new documents and orders. Also we get requests and complaints about the government of disabled families from the other side. We arrange meetings with parents and families and record their thoughts and needs and make a report.

Sometimes, we cooperate with the Sunshine Home as well. One time, after a child was absent for several days, they called me to help the child's mother make a report to the local police. They also call me in if any children have been in a fight and need their parents to be there.

Q: Do you plan some of the activities as well?

Yang's mother: We help with the drum band's weekend training at the district DPF center. There are eight subdistrict offices in the district; the children stay in their own subdistrict run Sunshine Home from Monday to Friday, but some of them come to the district DPF center for special practice at the weekend; it's on the Guangzhong Branch Road. We train them with the side drum or teach them dance. 
Why do we help the children with practice? One reason is these children are always indoors when they study at the homes. We want them do more exercise and get a chance to socialize with other children. We have the same situation here, parents develop friendships with each other, and the children, too. These children can't make friends with normal children; they can't even get on with their own relatives' children. An ordinary and a disabled child behave in very different ways; they don't have much in common. But all the children in our team are the same; they chat and play with each other very well because they are in the same situation. They are happy in each other's company.

The children come every weekend, it doesn't matter what the weather's like, windy or rainy, cold or hot; there are usually 50-60 children on a Saturday. I'll always be there for them even if I don't feel great, or if I'm sick.

Why do I have to go? There are lots of parents with disabled children from the Sunshine Home; they never talk about their problems to anybody because they don't dare to let other people know that their children are different. After I retired, I spend most of the time at home, and I go to the district DPF office for meetings or other businesses from time to time. So, at the weekend, after 5 days at home, our volunteer/teachers-we have ten teachers volunteering at the same time in the team-want to meet and catch up with the news. Sometimes we just talk about what we've done at home during the week. Outsiders can't understand us, my husband is my only audience at home, but at the center, we get a chance to open our hearts.

There are seven teachers, we are all good friends, sometimes we go on trips together, self-financed journeys, we've been to Japan, South Korea, Yunnan, and the Yangtze Gorges. We visited Zhangjiajie this August.

I can't take my son to my old classmate's party, I just can't take him there. What should I do if I have to leave my son at home while I go out? He would just follow me. I used to keep him company as well. Some of my old classmates are going on a 3-day trip next month, but I won't go. I feel a little bit down when we're together; I don't have much to share with them. I can't join in the gossip. They talk about somebody's child who's getting married, or they've got a newborn grandchild, but my child will never get married. Anyway, I have nothing to share with them and that's the reason I don't like to spend time with them.

Teachers and parents join together with the children for all our trips. It doesn't matter when and where we go, even on a week-long trip. I always feel easier when my child is with me, even though sometimes it's quite exhausting. Because they are different from their ordinary peers. My son can't help me carry stuff, and he's a slow walker, I have to do everything, but I just feel safer and can relax if he's with me.

\section{There Are Some People Who Despise My Son}

Yang's mother: Since he was born, I really... I cried all the time. There would always be somebody staring and pointing at him whenever I took him out. Once, when we were on a bus, a man stared at him for a long time, very long, it made me very 
angry. So I turned my son to face the guy and thought: if you like to stare at him, I'll just let you do it! This kind of thing really broke my heart. When I worked at the cotton factory, I never talked about my son with my colleagues, I was worried that I'd lose face if they knew my son was different. When they talked about their college children, daughters getting married, it always upset me. It broke my heart; I can't tell you how many times I cried.

When he started school, the tuition fees were quite high, over 600 yuan a semester. So I saved 100 yuan every month. After 6 months, at the beginning of the new semester, I used the money to pay the fee. His paternal auntie said to me: "You shouldn't send him to school, it's just a waste of money!" I was very angry and told her: "Did I borrow the money from you? It's my money, why can't I send him to school? Education is good for him." Both his paternal uncle and auntie looked down on him.

Q: Did people say anything bad about him when he went out with his grandpa?

Yang's mother: His grandpa never told me if they did, he usually only went to a relative's place to play mahjong. These people would never say bad things to his face. His dad would take him to business dinners with colleagues quite often. His paternal grandpa and grandma, maternal grandma, and big auntie don't hold anything against him, only his paternal uncle and auntie. But my son doesn't like to talk to them either.

Q: You just said his paternal uncle and his wife live at the same place with you, right?

Yang's mother: Yes, we still live together.

Q: But you said you don't get on very well with them.

Yang's mother: We've always had a bad relationship, even today. His paternal auntie insulted him only last month.

Q: What's the main problem between the two families? Is it about the child?

Yang's mother: How can I say this, it's just the small things that come from living together; there are always some everyday frictions. But he isn't their problem; they shouldn't insult us when there's a problem. They just take it out on my son when the two families argue, and they despise him at the same time.

Q: You said his paternal auntie had bad opinions about your son; has she changed mind now?

Yang's mother: Yes, their opinion has changed. They said to me: "Only you could raise a child like this. If we were in your situation, he probably wouldn't grow up as well as this. You sacrificed so much for him."

Q: You have made a lot of effort.

Yang's mother: I think about it this way, when those teachers spend so much attention on the children like my son, as his mother, how could I stand by and do nothing? I like to do everything for my child and that's why I became a volunteer. I would never have joined the district DPF volunteer team if it wasn't for him. Someone like you, a college student, and your parents could never know about the Sunshine Home or the disabled children's drum team. Only the parents of these special children know about the institutions for them, where there are special activities for them. 


\section{Want Him to Have a Good Life}

Q: Does Wei Yang get any welfare benefits from the government?

Yang's mother: One welfare benefit helps to keep him at the home; the place is free and provides free meals as well. He also gets a salary, a severely disabled and unemployed person's salary, which is in two parts, 1,150 yuan and 330 yuan go into his account separately. He also gets 150 yuan nursing allowance monthly.

Q: Has he been getting these benefits from a young age?

Yang's mother: He started receiving benefits quite early, when he was 18. You need an ID card to prove your identity to get welfare, and you have to be an adult first. But I don't know if there is a new policy for younger children today.

Q: Did you discuss your son's future with your family when he was at school?

Yang's mother: We didn't. Because in our family, his paternal uncle scorns him, and his grandpa and grandma are too old to talk about this issue. His paternal auntie disagreed about my son going to school; we couldn't talk about this with her either. I only discussed it with his dad. We made an agreement to try our best to make him happier, and satisfy his needs while he is living with us.

How can we have any hope for his future, even though we don't wish for very much? Can there a bright future for a child like him? Even though he was able to go to university, there won't be a big difference when he graduates. Can the government provide him with a job? It's impossible! So many college graduates are unemployed today. For a child like him it's even worse. When I think about everything I have done for him, at least I can say I treated him well.

Q: Did you ever think about letting him learn some vocational skills?

Yang's mother: At the moment he doesn't seem to want to learn any kind of job skills. I can't really tell what he wants to do right now. I think, I'd like to pay for his training if that's what he wants to do. I don't mind what he wants to do, I just try my best to support him. I buy everything he wants if I can afford it; it doesn't matter whether it's clothes or shoes, but I also told him we can't afford branded stuff. We won't let him get things that look worse than other children. Wearing clean, tidy and decent clothes is the rule. If he tells me he wants a new phone, I'll definitely buy one if I can afford it. Or, if he wants a new pair of shoes and I have the money he can have them. But, I can't tell what he wants to study at this moment, so I don't want to force him.

Q: What would you wish for him in the future?

Yang's mother: A job, he wants to work. For me, it's impossible because he doesn't have any real practical abilities. We have to take some responsibility for this. As you can see, this place... the stairs are so narrow, I worry about he might fall down when he's walking up and down, so I stopped him doing housework. He just needs to relax and play at home. The one thing we really want is for him to look after himself, to do his own thing. If one day we move to a new place, I'll teach him to do some housework. His dad can teach him to cook, but we can't do this now.

Thinking about his future, I just want him to earn a little bit more money than he gets now. He only earns over 1,000 yuan, but it's not enough for him! He won't be 
able to depend on us forever, what will happen to him when we pass away? There's a big income gap in the disabled group, some children with a milder condition can work, or they're affiliated to a company and can earn more money. Then they get the subsistence allowance at 20 years old, over 2,000 yuan monthly. But our son is severely disabled and unemployed; he earns much less than other children.

Also, he has free Medicare, but he has to visit certain hospitals. There is a Medicare-designated department at the district hospitals, but if he needs a transfer to a city hospital, he needs special documents. For example, he needs special medicine for his diabetes; it's an inherited disease, his grandparents and dad have it. In the beginning, he just visited the local hospital when his blood sugar level was high. Then I would take him to Xinhua Hospital and he was treated with a special prescription. His condition is now under control. Transferring him from the local hospital to Xinhua Hospital required a lot of paperwork every 3 months, and we had to repeat the whole procedure every 3 months. At the moment, we can help him, but I'm 60, his dad is 65; we won't be able to do this in 10 years. What will he do then? He can't do this on his own! So the best solution is to allow him to go to choose the higher level hospital and go on his own. That's one of our worries for the future.

\section{Some Stories Are Unforgettable}

Q: As well as the stories you've already told us, could you tell us something else that impressed you about his development?

Yang's mother: The happiest thing for me was his first performance after he joined the drum team. I was so glad to see him do this. I'd never seen him on stage before. That was a dragon dance, and he was dancing with the dragon ball on stage at the Shanghai Television Station. He'd also been in a dance show in Beijing.

In another show, a choral performance, he was the conductor of the choir. It was very successful, so many people applauded, but the evening before the performance we were so worried because the rehearsal didn't go well. When I was sitting in the audience, I was thinking, years ago these disabled children never had this opportunity; they were brought up to beg and scavenge for food from rubbish in the streets. But my son is up on stage, giving a wonderful performance, I was... so glad. Since then, my optimism gets stronger and stronger. I feel better for having the other teachers in my life: I was always depressed before. At the end of this month, we're going to do another show, at the annual convention of a well-known company; they've also invited lots of famous stars, as well as us.

Q: What's your son's best characteristic?

Yang's mother: He's totally changed, probably because now he has his own ideas, he isn't as naive and simple as he was when he was younger. And I think he's very different from other children; he's always interested in adult things, even though some aren't his business.

Apart from this, he's a bit of a lazy boy; he doesn't like exercise. He just plays with his computer, it's the only thing he likes to do after dinner. 
Q: How about housework like folding his clothes?

Yang's mother: He'll do some housework when I'm not at home. Also, if he thinks I'm in a good mood, he won't do anything, but if I'm in a bad mood, he'll offer to help. He's really good at reading people's moods and thoughts.

$\mathrm{Q}$ : Could you talk about his virtues?

Yang's mother: He's a caring person and worries about me if I'm sick; he gets concerned about whether I've taken my pills or not, often asking me if I want to eat or drink. Maybe that's because I'm the person who looks after him every day. He doesn't worry about his dad in the same way. He's also very respectful; for example, he always remembers his maternal grandma's birthday.

Q: What did his development bring to your life?

Yang's mother: A child who was born disabled to grows up like this, I'm very pleased. You see, ordinary children would never stay with their parents every day, but he has to. At his age, an ordinary child would be married and settled down and have his own life. If it was like that for us, we'd already have an empty nest. At this moment, I feel fulfilled and delighted with my son.

\section{Interview with Wei Yang's Teacher}

Interviewee: Wei Yang's teacher

Interviewer and Writer: Fengzhi Liu

Interview date: May 2, 2017

Interview place: Sunshine Home in Hongkou District, Shanghai

Q: When did you meet Wei Yang?

Teacher: I met Wei Yang in 2009 when two subdistrict Sunshine Homes merged.

Q: He wasn't a student of this home before the merger?

Teacher: He was with us before, at that time we merged two of the homes, and just kept the home we're in right now but closed the other one.

Q: Are there more students than before?

Teacher: For sure. We don't have many children, probably a dozen, more or less, in this street, but there's another street with over 20 children. But some children moved out of this area because of relocation. If all of them had come here, we would have had more than 30 students.

Q: What was your impression at the very beginning?

Teacher: It was fine. He is a... how to explain, a very obedient child, he tends to listen to the teacher's orders most of the time.

Q: How's his relationship with his classmates?

Teacher: Pretty good, he gets on very well with them, but he's a bit naughty sometimes; anyway, he's a boy!

Q: What do you mean by a bit "naughty"?

Teacher: I mean boy's behavior; you hit me and I hit you back, this kind of thing.

Q: Does he have any good friends in the class? 
Teacher: Yes, he's friendly with Lin; normally our children are on friendly terms.

Q: How about his relation with the teachers?

Teacher: Not too bad, he doesn't argue or challenge the teachers. He usually does what they ask him.

Q: What courses do you have?

Teacher: Education and training, rehabilitation training, Special Olympics training, inclusive activities, life skills, and simple housework training.

Q: What do they do in the education and training class?

Teacher: The education and training course includes Chinese, mathematics, and English, just teaching some very basic knowledge.

Q: Are they different to the courses at the Special School?

Teacher: There're some differences. We have an uneven level of student ability; our teaching context is too simple for some students who have very strong learning and studying abilities. But for some other children, they struggle with the pace of teaching. They're unable to learn effectively; they easily forget things, even something they might have been taught the previous day. We have to repeat the same things over and over. We have a higher requirement for quick learners, but for those weaker students we have to go over the lessons again and again.

Q: I attended their abacus class last time. What do they do in other classes, like the Chinese class?

Teacher: In the Chinese class we're teaching Tang Dynasty poetry, but we don't have a textbook. The Sunshine Homes don't have standard textbooks; we just choose some suitable poems. They are good at reciting the Three Character Classic, ${ }^{18}$ for example.

Q: What are the inclusive activities?

Teacher: Sessions that deal with hand-eye coordination, include finger exercises, basic body exercises, and several sets of radio calisthenics. Bad hand-eye coordination is a common problem with intellectually disabled children.

Q: You mentioned the class for Special Olympics; what's the schedule for this? Do you have training every day, or one session every week?

Teacher: It's part of our weekly schedule, two or three sessions a week. We're short of space, so we just let them play poker, badminton, and ball games.

Q: Do you have a fixed daily timetable?

Teacher: Yes. A very important part of their daily timetable is to help with the cooking. We have four teachers at the home, one is a cook, one of the other three takes turns to help.

Q: Do you cook for the students?

Teacher: We always cook, it's part of our tradition. We don't serve takeaway food; parents think home cooking is better for the children. Also, our budget isn't big enough to buy takeaway food for the whole month, cooking is the only way we can provide a free lunch for the children. Some homes serve takeaway food, 15 yuan

\footnotetext{
${ }^{18}$ The Three Character Classic called San Zi Jing in Chinese, has been one of most classic texts for the formal education of young children from the Song dynasty to the late 1800s. The text is written in triplets of characters so it can be memorized easily.
} 
each box, 150 yuan for each person's budget, but it's only enough for ten meals. After that, the children have to pay for their own lunch. But we resolved the low budget problem with home cooking. So the children like it here, our free meals are tasty and healthy, some takeaway food's quality isn't guaranteed.

Q: Do the students help the teachers cook?

Teacher: Yes, of course. It's the season for broad beans, so we usually buy a lot and let the children peel them. Sometimes they also do simple house work, domestic training, teaching them to make wonton, dumplings, some basic cooking skills. Sometimes volunteers come here to teach them how to make sweet dumplings and they'll share the food together afterwards.

Q: Do you get volunteers for activities very often?

Teacher: Yes, they always come after Spring Festival, but that tends to drop off after a couple of weeks. Most of them are local residents; one good-hearted man who works for the Children's Art Troupe, visits the children every year.

Q: In your opinion, what do his classmates think about Wei Yang?

Teacher: His behavior is just so-so, sometimes he's naughty, he's a person who will fight with other students. Some students don't like his attitude, but the others like him a lot.

Q: Is he an active boy?

Teacher: Yes, he's quite active.

Q: What's his performance like in the classroom?

Teacher: Pretty good, he likes to answer the questions he knows, but hides away if there's something he doesn't know.

Q: What's his favorite course?

Teacher: He's good at dancing, because his mom is the choreographer of the district DPF dance team; they practice every weekend. He always enjoys it, and he's very active in these sessions.

Q: How about other courses? Is he an active learner, in the abacus class for example?

Teacher: In the beginning, he was very reluctant to get involved with this class. He told me he's not interested and refused to read the textbook. I pushed him to study, even though he tried to give the book back to me. But he's getting better now he understands more.

Q: What do you think about his ability compared to his classmates at the home?

Teacher: He's just about okay, he isn't one of the stronger ones. We have several children with outstanding ability; they usually help the teachers with their duties. We also have some simple life skills training to help them develop their independence. We teach them how to go shopping, but he has no interest in this area.

He doesn't like to help other children, he only cares about himself. But some children, those who are close to him in the class, he'll help them, but not the ones he doesn't really know. I let him lead a student group when we went out for an activity and he really engaged with that role. Children like him really love to be flattered; a little encouragement helps their self-confidence.

Q: Yang is in his thirties. What is the average age of the students? 
Teacher: They are between 16 and 35, but we also have several in their forties, even though there is a government policy that those over 35 have to leave. Some parents tell us their children have nowhere to go if they leave the home, so we just keep them here temporarily if they don't want to go. It's a flexible rule, we have more students in their forties in our community than most other places; three or four, but other homes won't let the over-aged students stay.

Q: Are the extra students a burden?

Teacher: Of course. When the children graduate from the Special School at Miyun Road, I always find a space to squeeze them in if their parents ask me. But we won't get any more funding from the government after they are 35 . There's nothing we can do but ask our subdistrict office to extend their expenses for the home.

Q: Do they go back home when they leave at 35 years old?

Teacher: They still receive social care services when they go back home, the carers will go to do their washing and cooking every day, but they prefer to be here- the more people, the more fun. They get lonely when their parents have to go out, but if they come here they can always socialize with other children.

Q: I've been told by Wei Yang's mother, that he came here in 2005, so he's one of the old students?

Teacher: He's been here for years, since we opened.

Q: Do you think he's changed since you met him in 2009 ?

Teacher: He's changed a lot. Now he's a very independent person. We take them to a 3- to 4-day training camp without their parents every year. They have to look after themselves - washing, cleaning, eating - he's on top of all of these duties. This is something he couldn't do before. Now he can even help the others; he's a leader at the Sunshine Camp. Now, he's able to go shopping on his own. Usually we don't encourage them to buy things, but he's so excited to buy his own snacks after he finishes here at three clock. Anyway, he has good independent life skills.

Q: Wei Yang's mother said he likes history books very much.

Teacher: Yes, yes. We don't have many books, people don't donate books to us, but the volunteers brought some books when we moved here in 2009. He just kept reading these books all the time. He always reads after lunch, I'm not sure if he borrows books from elsewhere.

Q: So he's a student who enjoys reading very much?

Teacher: He'll read if they aren't allowed to watch TV in their free time in the afternoon. He likes to watch Running Boys and Girls from Anhui Satellite Television.

Q: What do students usually do in their free time?

Teacher: Playing poker, chess, or chatting.

$\mathrm{Q}$ : Is there much conflict between the students?

Teacher: They are good-hearted people, they always make up again within minutes after they've argued, and they won't hold a grudge for very long.

Q: Does Wei Yang like to chat with the teachers?

Teacher: He'll chat with me if he's been somewhere with his mom. They visited Thailand last week and he showed me his pictures. He also brought some Thai snacks for the other children. His mom takes him on several trips every year, but some parents never do that. His mom cares about him very much. 
Q: Does the home arrange trips for students?

Teacher: We've just received approval for doing this by the district DPF office, but we haven't been on a trip yet. It's the old concerns; security reasons stop us from going out. Actually, the students are all very well behaved when they go out. When we took them to Heping Park, they were so excited, they really want to go somewhere together. We used to take them to karaoke for several years, and they were always completely delighted.

Q: I heard that Wei Yang isn't in good health, he has diabetes, right?

Teacher: Yes, but he won't give up sweets. He insists he shouldn't eat sweet congee if we serve it for lunch. But then sometimes he just runs off to a local shop for soft drinks after school. I told him these drinks are high in sugar as well, and he shouldn't have them, but he won't listen to me. We have several children who have hyperglycemia, hyperlipidemia, and hypertension or HTN, and they love meat so much, what can you do except buy meat, they won't touch vegetable dishes? Sometimes we buy some steamed bread for them for a change. But Wei Yang won't stop drinking sugary drinks; there is nothing we can do.

Q: Has he done anything in particular, or does he have a special character that's impressed you?

Teacher: The most impressive thing about him is his stubbornness, if he is in that kind of mood, he will ignore anything you say. Once, it was Labor Day or National Day, the home had to close early, and we told everyone to go home early. I told him to call his parents and let they know this change, but he was determined not to. This thing really impressed me. When one of our teachers, a cook, told Wei Yang he has to listen to the teachers, he said: "Aunt, you only need to care about the cooking and mind your own business."

Q: That's all, I'm sorry for keeping you such a long time today.

Teacher: No problem at all, just give me a ring if you have any more questions.

Q: That's great, thank you again!

\section{Interview with Wei Yang}

Interviewee: Wei Yang

Interviewer and writer: Fengzhi Liu

Interview dates: November 27 and December 14, 2016

Interview places: Hongkou District Disabled Persons' Federation, Shanghai, a Sunshine Home in Hongkou District

Q: Are you used to being at the Sunshine Home, now?

Yang: I started coming here in 2005 and started playing the side drum in 2005.

Q: So it's 11 years. A very long time, isn't it?

Yang: Yes, quite a long time.

Q: Teacher Zhou told me that you're a star in the band!

Yang: I went to Beijing in 2009. 
Q: What did you do in Beijing?

Yang: A performance with Bingbing Li. Because Tiananmen Square was being refurbished, so we didn't go there.

Q: Do you like to play the side drum?

Yang: I do, Teacher Zhou told me to do it.

Q: Do you do radio calisthenics every day?

Yang: We exercise every day except it's too hot. We'll start again when the weather gets cooler.

Q: What do you usually do here?

Yang: Usually we have rehabilitation training, social interaction, and Special Olympics activities, all of those.

Q: When do you have the Special Olympics activities?

Yang: The Sunshine Home doesn't have it; we have to go to the district DPF center for it.

Q: How long have you been involved in the Special Olympics activities?

Yang: When I left school.

\section{Observation of Wei Yang at the Sunshine Home}

Observation date: 9:00-15:00, December 14, 2016

Observation place: Sunshine Home in Hongkou District

Observer and writer: Fengzhi Liu

\begin{tabular}{l|l|l}
\hline Time & Content & Observed activities \\
\hline $9: 00$ & Class starts & $\begin{array}{l}\text { Wei Yang is late. His mother said he } \\
\text { might come later, it's because of the } \\
\text { cold weather. Wei Yang left home } \\
\text { with his mother, but then he went for } \\
\text { breakfast }\end{array}$ \\
\hline $9: 02$ & Wei Yang arrives & $\begin{array}{l}\text { He sits in the front row, with a } \\
\text { fluorescent yellow coat }\end{array}$ \\
\hline $9: 03$ & Wei Yang greets m & $\begin{array}{l}\text { He nods his head without talking } \\
\text { when he sees the observer }\end{array}$ \\
\hline $9: 05-9: 15$ & Watching TV & $\begin{array}{l}\text { Wei Yang is discussing something } \\
\text { with a classmate and gives a piece } \\
\text { paper to him. Compared with the } \\
\text { other students, he's quiet, watches the } \\
\text { TV occasionally. During this time, he } \\
\text { looks back many times; he might look } \\
\text { at his mother or just out of habit }\end{array}$ \\
\hline
\end{tabular}

(continued) 
(continued)

\begin{tabular}{|c|c|c|}
\hline Time & Content & Observed activities \\
\hline $9: 17-9: 19$ & Preparing for an exercise & $\begin{array}{l}\text { He has a short talk with a classmate } \\
\text { across the class, puts his coat back on } \\
\text { and gets ready }\end{array}$ \\
\hline $9: 20-9: 24$ & $\begin{array}{l}\text { Practicing the people's radio } \\
\text { calisthenics }\end{array}$ & $\begin{array}{l}\text { They practice the ninth edition of the } \\
\text { people's radio calisthenics. Wei Yang } \\
\text { doesn't move very much, mostly } \\
\text { upper body movements, and he hardly } \\
\text { moves his legs. He is smiling or } \\
\text { looking at classmates during the } \\
\text { exercise }\end{array}$ \\
\hline $9: 24-9: 26$ & $\begin{array}{l}\text { Practicing another set radio } \\
\text { calisthenics }\end{array}$ & $\begin{array}{l}\text { Students exercising and singing a song } \\
\text { about the Sunshine Home. But Wei } \\
\text { Yang only does simple actions, he } \\
\text { doesn't sing }\end{array}$ \\
\hline $9: 26-9: 31$ & Preparing exercises & $\begin{array}{l}\text { Most of this part is about finger } \\
\text { exercise, Wei Yang doesn't do very } \\
\text { much, he smiles occasionally. During } \\
\text { the exercise, Wei Yang looks at the } \\
\text { room where a student's parent enters }\end{array}$ \\
\hline $9: 31-9: 39$ & Waiting for class & $\begin{array}{l}\text { Wei Yang gets some water from the } \\
\text { water dispenser after the exercise and } \\
\text { asks the observer if she wants to have } \\
\text { some water. The observer declines } \\
\text { gently. Then he walks back to his seat. } \\
\text { Wei Yang is searching in his bag for } \\
\text { school things when the teacher asks } \\
\text { people to find their exercise book and } \\
\text { abacus }\end{array}$ \\
\hline $9: 40-9: 48$ & $\begin{array}{l}\text { Teacher switches off the TV, to } \\
\text { prepare for a class }\end{array}$ & $\begin{array}{l}\text { It takes a while for the teacher to sort } \\
\text { out the whiteboard. Wei Yang doesn't } \\
\text { come to help, but he is concerned. He } \\
\text { watches the teacher all the time }\end{array}$ \\
\hline $9: 48-9: 55$ & Wei Yang goes to the bathroom & $\begin{array}{l}\text { Wei Yang gets some tissue from the } \\
\text { drawer to wipe his nose. He takes off } \\
\text { his coat. His classmate's mother tells } \\
\text { the observer: the class starts at } 10 \text {; } \\
\text { they will have lunch here; take a nap } \\
\text { after lunch; and the students will head } \\
\text { back home at } 3 \text {. Some children with } \\
\text { more ability will help the teacher with } \\
\text { their duties }\end{array}$ \\
\hline
\end{tabular}


(continued)

\begin{tabular}{|c|c|c|}
\hline Time & Content & Observed activities \\
\hline $9: 55-10: 00$ & Teacher and students are chatting & $\begin{array}{l}\text { They talk about the content of today's } \\
\text { lesson, some students say it's too } \\
\text { complicated, but the teacher says they } \\
\text { just need to keep working on the } \\
\text { simplest addition and subtraction } \\
\text { questions. Wei Yang doesn't say } \\
\text { anything }\end{array}$ \\
\hline 10:00 & Class starts & $\begin{array}{l}\text { They are reading the abacus rhymes } \\
\text { and doing finger exercise for a minute }\end{array}$ \\
\hline 10:01-10:02 & $\begin{array}{l}\text { The teacher asks the students to work } \\
\text { on the first question }\end{array}$ & $\begin{array}{l}\text { The teacher lets a student show the } \\
\text { class how to do "plus 7" on the abacus } \\
\text { on the blackboard. Wei Yang repeats } \\
\text { the action after the classmate's } \\
\text { demonstration }\end{array}$ \\
\hline 10:02-10:04 & $\begin{array}{l}\text { The teacher asks Wei Yang to come to } \\
\text { the front to do a demonstration }\end{array}$ & $\begin{array}{l}\text { This question is about "plus } 4 . \text {." Wei } \\
\text { Yang rearranges the abacus, and then } \\
\text { finishes the teacher's instruction } \\
\text { successfully. The teacher praises his } \\
\text { smooth finger movements, and the } \\
\text { students applaud him. He smiles } \\
\text { before going back to his seat }\end{array}$ \\
\hline 10:06-10:09 & $\begin{array}{l}\text { The teacher lets the students practice } \\
\text { two questions together continuously } \\
\text { and quickly }\end{array}$ & $\begin{array}{l}\text { The exercises are "plus } 8 \text { on two } \\
\text { abacus bars" and "subtract } 8 \text { from two } \\
\text { bars." Wei Yang looks at his desk } \\
\text { mate's exercise during his own } \\
\text { practice. The teacher asks one student } \\
\text { to perform the questions at the front } \\
\text { later }\end{array}$ \\
\hline 10:09-10:10 & Double figure exercise & $\begin{array}{l}\text { The teacher lets them practice "add } \\
16 \text { " and "subtract } 16 \text {," and also } \\
\text { reminds them which way they should } \\
\text { start. The teacher asks for a volunteer, } \\
\text { but the first student has to finish their } \\
\text { practice with the teacher's help. Wei } \\
\text { Yang is watching this student's } \\
\text { practice after he finishes his own work }\end{array}$ \\
\hline 10:11-10:15 & The difficulty of the exercise increases & $\begin{array}{l}\text { Wei Yang raises his hand to be a } \\
\text { volunteer, but the teacher chooses } \\
\text { somebody else. Wei Yang is watching } \\
\text { the classmate's performance }\end{array}$ \\
\hline $10: 15$ & Practice to plus ' 92467 ' & $\begin{array}{l}\text { Wei Yang raises his hand first when } \\
\text { the teacher asks who has finished }\end{array}$ \\
\hline $10: 20$ & Practice to plus ' 340971 ' & $\begin{array}{l}\text { The teacher asks Wei Yang to practice } \\
\text { at the front, he does the job } \\
\text { successfully }\end{array}$ \\
\hline
\end{tabular}


(continued)

\begin{tabular}{|c|c|c|}
\hline Time & Content & Observed activities \\
\hline $10: 22-10: 24$ & $\begin{array}{l}\text { Practicing " } 2+1-2+5-1+4 \text { " } \\
\text { with fingers to simulate calculation } \\
\text { using the abacus }\end{array}$ & $\begin{array}{l}\text { Wei Yang does his exercise correctly } \\
\text { and chews his fingers while he } \\
\text { practices }\end{array}$ \\
\hline $10: 25$ & More practice & $\begin{array}{l}\text { The teacher asks for a volunteer for } \\
\text { the demonstration, but Wei Yang } \\
\text { keeps his head down, the teacher can't } \\
\text { see what he is doing }\end{array}$ \\
\hline 10:28 & $\begin{array}{l}\text { The teacher asks Wei Yang to do the } \\
\text { demonstration, but he refused }\end{array}$ & $\begin{array}{l}\text { Wei Yang tells the teacher: "I really } \\
\text { can't do it; my hands aren't good } \\
\text { enough." Because of his fingers' poor } \\
\text { flexibility, he can't do the exercise. } \\
\text { Some other students volunteered }\end{array}$ \\
\hline $10: 29-10: 33$ & Break time & Wei Yang doesn't leave his seat \\
\hline 10:34 & $\begin{array}{l}\text { Wei Yang leaves his seat to get some } \\
\text { water }\end{array}$ & \\
\hline $10: 36-10: 40$ & $\begin{array}{l}\text { Wei Yang is walking around and } \\
\text { talking with his classmates }\end{array}$ & $\begin{array}{l}\text { They are talking in Shanghai dialect } \\
\text { some distance away and the observer } \\
\text { can't hear what they are saying }\end{array}$ \\
\hline $10: 41$ & Reading abacus rhymes & \\
\hline $10: 43$ & Doing practice in the exercise book & $\begin{array}{l}\text { Wei Yang is taking the task quite } \\
\text { seriously }\end{array}$ \\
\hline $10: 47$ & $\begin{array}{l}\text { The teacher walks around and asks } \\
\text { them about their practice }\end{array}$ & $\begin{array}{l}\text { Some students have finished the } \\
\text { practice while Wei Yang is still } \\
\text { working, so he doesn't raise his hand } \\
\text { to answer the teacher's question }\end{array}$ \\
\hline $10: 49-10: 57$ & Classmate demonstration & $\begin{array}{l}\text { Wei Yang is bending his head, not } \\
\text { sure if he is correct or not. More or } \\
\text { less half the students have problems } \\
\text { with this part of the abacus exercise }\end{array}$ \\
\hline 10:57-10:58 & $\begin{array}{l}\text { The teacher asks if anybody has } \\
\text { finished the exercises from another } \\
\text { page }\end{array}$ & Wei Yang raises hand \\
\hline 11:01-11:02 & $\begin{array}{l}\text { The teacher asks if anybody has } \\
\text { finished again }\end{array}$ & Wei Yang doesn't raise his hand \\
\hline 11:02-11:05 & Classmate demonstration. & $\begin{array}{l}\text { Wei Yang concentrates on his own } \\
\text { exercise, he doesn't raise his head }\end{array}$ \\
\hline 11:05-11:06 & $\begin{array}{l}\text { The teacher lets the students pack } \\
\text { their exercise book and abacus away }\end{array}$ & $\begin{array}{l}\text { Wei Yang packs his stuff up very } \\
\text { quickly }\end{array}$ \\
\hline 11:06 & $\begin{array}{l}\text { The class has finished. The students } \\
\text { on duty are cleaning up }\end{array}$ & Wei Yang is packing up his stuff \\
\hline
\end{tabular}


(continued)

\begin{tabular}{|c|c|c|}
\hline Time & Content & Observed activities \\
\hline $11: 25$ & Queuing for lunch & $\begin{array}{l}\text { Wei Yang and his classmates go to the } \\
\text { canteen. The place is opposite the } \\
\text { classroom, and they form a queue to } \\
\text { collect their food. The lunch is tomato } \\
\text { and egg soup, pork chops and a } \\
\text { marinated egg, and a banana for } \\
\text { dessert }\end{array}$ \\
\hline $12: 00-12: 27$ & Playing with his phone & $\begin{array}{l}\text { Wei Yang is sitting down and playing } \\
\text { with his mobile phone after lunch, he } \\
\text { doesn't talk to other people }\end{array}$ \\
\hline $12: 27-12: 35$ & $\begin{array}{l}\text { He puts the phone away and watches } \\
\text { TV }\end{array}$ & $\begin{array}{l}\text { Wei Yang isn't watching the TV news } \\
\text { all the time, and looks somewhere else } \\
\text { quite often }\end{array}$ \\
\hline 12:35-13:00 & Having a nap at his desk & $\begin{array}{l}\text { The classroom is very quiet at this } \\
\text { time }\end{array}$ \\
\hline $13: 00-13: 26$ & A cooking program is playing on $\mathrm{TV}$ & $\begin{array}{l}\text { Wei Yang isn't interested in this } \\
\text { program, he leans on his desk and } \\
\text { looks around }\end{array}$ \\
\hline $13: 26-13: 29$ & Preparing for the next class & $\begin{array}{l}\text { The desk mate wakes Wei Yang up, } \\
\text { but he still leans on his desk }\end{array}$ \\
\hline $13: 29$ & $\begin{array}{l}\text { The teacher tells Wei Yang to sit up } \\
\text { and prepare for the class }\end{array}$ & \\
\hline $13: 31-13: 40$ & $\begin{array}{l}\text { For the afternoon's entertainment, the } \\
\text { students need to warm up first }\end{array}$ & $\begin{array}{l}\text { Wei Yang and his classmates stand up } \\
\text { from their seats. The teacher tells } \\
\text { them to clap their hands } 100 \text { times; } \\
\text { they hit their palms and tap their } \\
\text { fingers } 36 \text { times in each session. Wei } \\
\text { Yang's actions aren't quite correct, } \\
\text { and in a faster rhythm. Wei Yang } \\
\text { keeps doing the exercises but doesn't } \\
\text { have eye contact with the teacher. The } \\
\text { students become very excited, } \\
\text { practicing in a lively way }\end{array}$ \\
\hline $13: 40-13: 43$ & The teacher takes a look at Wei Yang & $\begin{array}{l}\text { The teacher spends a lot of attention } \\
\text { on Wei Yang }\end{array}$ \\
\hline $13: 43-13: 46$ & & $\begin{array}{l}\text { Wei Yang moves less and less, getting } \\
\text { less involved with the exercise than } \\
\text { before }\end{array}$ \\
\hline $13: 46$ & The activities are finished & $\begin{array}{l}\text { The teacher tells Wei Yang he doesn't } \\
\text { do enough exercise and needs to do } \\
\text { more exercise for a healthy body. Wei } \\
\text { Yang walks back to his seat when the } \\
\text { other classmates go for water }\end{array}$ \\
\hline
\end{tabular}

(continued) 
(continued)

\begin{tabular}{|c|c|c|}
\hline Time & Content & Observed activities \\
\hline $13: 55$ & Entertainment time starts & $\begin{array}{l}\text { The teacher asks the students to sing, } \\
\text { Wei Yang is looking forward to the } \\
\text { other students' show, applauding very } \\
\text { happily }\end{array}$ \\
\hline $13: 55-13: 58$ & One male classmate sings & $\begin{array}{l}\text { A classmate sings Emil Chau's }{ }^{\mathrm{a}} \\
\text { Friend, but Wei Yang has his head } \\
\text { down during the performance }\end{array}$ \\
\hline 13:58-14:01 & Another male classmate sings & $\begin{array}{l}\text { The classmate sings My Happiness is } \\
\text { Thinking of You. Wei Yang's } \\
\text { humming alone; at the end, the whole } \\
\text { class is singing together }\end{array}$ \\
\hline 14:04-14:06 & Wei Yang sings & $\begin{array}{l}\text { Wei Yang sings Teresa Teng's }{ }^{\mathrm{b}} \text { If You } \\
\text { Asked How Much I love You. He } \\
\text { remembers most of the lyrics, and } \\
\text { only forgets a few words. He's totally } \\
\text { engaged in singing and gives a salute } \\
\text { at the end }\end{array}$ \\
\hline 14:06-14:08 & The fourth student sings & $\begin{array}{l}\text { The classmate sings Raining in the } \\
\text { Heart. Wei Yang is chatting with his } \\
\text { back turned to his classmate during } \\
\text { the performance }\end{array}$ \\
\hline $14: 08-14: 10$ & The fifth student sings & $\begin{array}{l}\text { A male student sings The Lapping } \\
\text { Waves of Honghu Lake. Wei Yang } \\
\text { doesn't watch the performance but } \\
\text { applauds him at the end }\end{array}$ \\
\hline $14: 10-14: 12$ & The sixth student sings & $\begin{array}{l}\text { A male student sings Little Apple. } \\
\text { Wei Yang is singing along. Wei Yang } \\
\text { looks very happy, laughing all the time }\end{array}$ \\
\hline $14: 12-14: 15$ & The seventh student sings & $\begin{array}{l}\text { A male student performs A Grateful } \\
\text { Heart with sign language. Wei Yang } \\
\text { is singing along without sign language }\end{array}$ \\
\hline $14: 15-14: 18$ & $\begin{array}{l}\text { The student who sang the second } \\
\text { song, sings the same one again }\end{array}$ & $\begin{array}{l}\text { The student sings My Happiness is } \\
\text { Thinking of You again. Wei Yang } \\
\text { looks very happy throughout the song }\end{array}$ \\
\hline $14: 18-14: 23$ & Three female students sing & $\begin{array}{l}\text { Three female students sing } M y \\
\text { Happiness is Thinking of You } \\
\text { together. Wei Yang is singing along. } \\
\text { When Wei Yang's mother walks in } \\
\text { though the back door, he turns back } \\
\text { and looks at her }\end{array}$ \\
\hline $14: 23-14: 29$ & One male student sings on the stage & $\begin{array}{l}\text { The student is singing Run to an } \\
\text { excited class, but Wei Yang isn't as } \\
\text { excited as his classmates. Actually, } \\
\text { Wei Yang is always calmer than the } \\
\text { other classmates }\end{array}$ \\
\hline
\end{tabular}


(continued)

\begin{tabular}{l|l|l}
\hline Time & Content & Observed activities \\
\hline $14: 29-14: 32$ & A female student sings & $\begin{array}{l}\text { Wei Yang plays with his phone when } \\
\text { the classmate sings Mouse Loves Rice }\end{array}$ \\
\hline 14:32-14:35 & A male student sings & $\begin{array}{l}\text { Wei Yang helps the singer hold the } \\
\text { phone for the music while the } \\
\text { classmate sings The Most Dazzling } \\
\text { Folk Style and Little Apple }\end{array}$ \\
\hline $14: 35-14: 40$ & $\begin{array}{l}\text { A male student sings the last song of } \\
\text { the entertainment session }\end{array}$ & $\begin{array}{l}\text { The last song is Stupid Child. Wei } \\
\text { Yang sings along with his classmates }\end{array}$ \\
\hline $14: 40$ & After school & $\begin{array}{l}\text { After school, he goes to the bathroom } \\
\text { while the students on duty start } \\
\text { cleaning up. His mother doesn't go } \\
\text { home with Wei Yang, she left earlier }\end{array}$ \\
\hline
\end{tabular}

${ }^{a}$ Emil Chau, a well-known Hong Kong-Taiwanese singer during the 1980s and 1990s

${ }^{b}$ Teresa Teng was a Taiwanese singer, one of the most famous Chinese-speaking singers in the world. She was popular in the 1970s and 1980s until she died in 1995

Translated by Huili Meng Edited by Russell Murray

Open Access This chapter is licensed under the terms of the Creative Commons AttributionNonCommercial-NoDerivatives 4.0 International License (http://creativecommons.org/licenses/bync-nd/4.0/), which permits any noncommercial use, sharing, distribution and reproduction in any medium or format, as long as you give appropriate credit to the original author(s) and the source, provide a link to the Creative Commons license and indicate if you modified the licensed material. You do not have permission under this license to share adapted material derived from this chapter or parts of it.

The images or other third party material in this chapter are included in the chapter's Creative Commons license, unless indicated otherwise in a credit line to the material. If material is not included in the chapter's Creative Commons license and your intended use is not permitted by statutory regulation or exceeds the permitted use, you will need to obtain permission directly from the copyright holder.

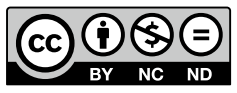

